\title{
Visual disturbances in man as a result of experimental and occupational exposure to dimethylethylamine
}

\author{
B Ståhlbom, T Lundh, I Florén, B Åkesson
}

\begin{abstract}
Experimental exposure of four volunteers to 40-50 $\mathrm{mg} / \mathrm{m}^{3}$ of dimethylethylamine (DMEA) for eight hours caused irritation of the mucous membrane of their eyes, subjective visual disturbances (haze), and slight oedema of the corneal epithelium. The thickness of the cornea showed a slight but consistent increase in all four subjects at these exposures and in two subjects exposed to $10 \mathrm{mg} / \mathrm{m}^{3}$. Concentrations of 80 and $160 \mathrm{mg} / \mathrm{m}^{3}$ for 15 minutes caused eye irritation but no visual disturbances or corneal oedema. Occupational exposure for eight hours to about $25 \mathrm{mg} / \mathrm{m}^{3}$ of DMEA (with peaks above $100 \mathrm{mg} / \mathrm{m}^{3}$ ) was also associated with eye irritation, haze, and corneal oedema. The divergence between our findings and other reports in which visual disturbances occurred at lower concentrations during occupational exposure may be due to peak concentrations.
\end{abstract}

Amines are components in many processes in the chemical and pharmaceutical industries. ${ }^{1}$ Several are used as catalysts in polymer production and they have an increasingly wide use as chemical intermediates in the production of pharmaceuticals, soaps, emulsifiers, dyestuffs, rubber products, flotation agents, finishing agents, and ion exchange resins. Amines are also employed as (and used in the production of) corrosion inhibitors and stabilising agents-for example, in water borne paints.

Tertiary aliphatic amines are widely employed as

Department of Occupational Medicine, University Hospital, S-581 85 Linköping, Sweden

B Stahlbom

Department of Occupational and Environmental Medicine

T Lundh, B Åkesson

and Department of Ophthalmology, University Hospital S-221 85 Lund, Sweden

I Florén catalysts in foundry and polyurethane foam manufacturing operations. Highly reactive amines are local irritants that affect the eyes, mucous membranes, and skin. ${ }^{2}$ They also cause visual disturbances such as mydriasis, cycloplegia, ${ }^{3-5}$ and haze (due to corneal oedema), ${ }^{6-8}$ and produce headache, nausea, and faintness. Also $\mathrm{N}$-methylmorpholine has been associated with bronchial hyperreactivity. ${ }^{7}$

Occupational exposure to $10-15 \mathrm{mg} / \mathrm{m}^{3}$ triethylamine (TEA) for an eight hour time weighted average (TWA) caused visual disturbances in polyurethane foam workers after one to six hours of work, which faded within one hour after work. ${ }^{9}$ Exposure to concentrations of less than $10 \mathrm{mg} / \mathrm{m}^{3}$ TEA did not provoke visual effects. Experimental exposure to $18-48 \mathrm{mg} / \mathrm{m}^{3}$ TEA (four to eight hour TWA) caused visual disturbances (hazy vision and halo effects). Ocular examination showed corneal oedema, conjunctival injections of the eyes strictly confined to the palpebral fissures, and a decrease in visual acuity. Pachymetry readings displayed an increase in corneal thickness. The visual disturbances were probably caused by a direct toxic effect of TEA on the epithelial cells of the cornea. The phenomena faded gradually and had disappeared after about four hours. Eight hours of exposure to $10 \mathrm{mg} / \mathrm{m}^{3}$ TEA had no effect. ${ }^{8}$

Occupational exposure to dimethylethylamine (DMEA) for eight hours at TWA concentrations of $6-10 \mathrm{mg} / \mathrm{m}^{3}$, or for 15 minutes at $29 \mathrm{mg} / \mathrm{m}^{3}$, caused transient visual disturbances among workers during core making operations. ${ }^{10}$ Other investigators reported the same adverse effects after exposure to $1 \cdot 1-$ $45 \mathrm{mg} / \mathrm{m}^{3}$ for eight hours and to $75-299 \mathrm{mg} / \mathrm{m}^{3}$ DMEA for 15 minutes. ${ }^{11-13}$

The visual effects may increase the risk of accidents at work, and after, and should thus determine the permissible exposure limit. Information on the threshold exposure, however, for such effects, is not sufficiently well known. Also, the pathophysiology of the effects caused by DMEA has not been studied.

We report the ocular effects of experimental and occupational exposure on man to various air concentrations of DMEA. 


\section{Methods}

SUBJECTS AND EXPOSURE

Experimental exposure

Four healthy male volunteers (subjects A, B, C, and D) who were non-smokers aged 33 to 53 (mean 43 years), participated in the experimental studies. Their body weights ranged from 75 to 88 (mean 80 ) $\mathrm{kg}$, and their heights from 1.78 to 1.84 (mean $1 \cdot 82) \mathrm{m}$. Subjects $\mathrm{A}$ and $\mathrm{B}$ wore glasses during all exposure studies.

The experimental studies were performed in an exposure chamber described in detail earlier. ${ }^{9}$ Dimethylethylamine vapour was administered to the air stream entering the chamber by an automatic infusion device. The DMEA (99\%) was obtained from Janssen Chemica (Beerse, Belgium). Experiments lasting 15 minutes were made without breaks, but during experiments for eight hours, an exposure free period of about five minutes was introduced after each two hours. The concentration of DMEA in the chamber was monitored continuously by an infrared gas analyser (MIRAN-1A; wavelength $9.3 \mu \mathrm{m}$; pathlength $20.25 \mathrm{~m}$ ). The air concentration of amine in the chamber was also determined during consecutive one hour sampling periods, by the method of Lundh, Ståhlbom, and Åkesson (unpublished data).

The experiments employed eight hour exposures to 10,20 (two subjects only), 40 , and $50 \mathrm{mg} / \mathrm{m}^{3}$, and 15 minute exposures to 80 and $160 \mathrm{mg} / \mathrm{m}^{3}$ DMEA.

Subjective perception of irritation and visual disturbances (haze, or halo effects, or both) were registered. Ophthalmological examinations were made after eight hours of work without exposure and 15-30 minutes after each exposure to DMEA. The examinations included visual acuity, slit lamp examination of the anterior segment of the eye, and ultrasonic pachymetry of the cornea (Storz CorneoScan; St Louis, MO, USA). Also, during and after exposure, subjective descriptions of the visual disturbances were obtained.

\section{Occupational exposure}

In the occupational setting, 12 core workers (10 men and two women, mean age 38 (range 23-62 years) were studied in four different foundries. The cores were made from a mixture of silica sand, liquid phenolic resin, and methylenediphenyldiisocyanate in a core box machine. This mixture was cured by a few seconds of exposure to DMEA. Dry air was then blown through the core to purge any remaining DMEA.

The TWA exposure concentration was measured for each worker in his or her personal breathing zone during the full work shift (eight hours), divided into sampling periods of around one hour.

During the days studied, the workers registered subjective perceptions of eye disturbances (haze, or irritation, or both) in connection with their work. Slit lamp examinations of the eyes were made after the end of work and in a free interval (after a weekend) for workers reporting symptoms of visual disturbance.

\section{Results}

EXPERIMENTAL EXPOSURE

Ophthalmological examinations before exposure showed no abnormalities. A visual acuity of 1.0 was obtained for all four subjects after correction.

\section{Eight hour exposure experiments}

Three subjects had eye irritation both at the 40 and $50 \mathrm{mg} / \mathrm{m}^{3}$ concentrations of DMEA (table). Visual disturbances (haze) were recorded three to seven hours after the start of exposure by all four subjects at $50 \mathrm{mg} / \mathrm{m}^{3}$, and by one subject after six hours at $40 \mathrm{mg} / \mathrm{m}^{3}$ DMEA. The effects faded within one to three hours after the end of the exposure.

Ocular examinations after the experiments showed oedema of the corneal epithelium in three of the four subjects at the exposure concentration of $50 \mathrm{mg} / \mathrm{m}^{3}$, but only in one subject at $40 \mathrm{mg} / \mathrm{m}^{3}$ DMEA (table). No sign of corneal oedema was found under the eyelids. Slight conjunctival injection was seen in the affected subjects. Visual acuity did not decrease. Corneal thickness showed a slight increase with exposure to DMEA in all subjects; it was present already with exposure to $10 \mathrm{mg} / \mathrm{m}^{3} \mathrm{DMEA}$ in two of them (figure).

No subjective effects were recorded in the four volunteers when exposed to 10 and $20 \mathrm{mg} / \mathrm{m}^{3}$ DMEA.

\section{Fifteen minute exposure experiments}

Exposure to concentrations of $80 \mathrm{mg} / \mathrm{m}^{3}$ or $160 \mathrm{mg} /$ $\mathrm{m}^{3}$ of DMEA did not result in any sign of corneal oedema or conjunctival injection, and no visual disturbances were recorded. Visual acuity was not affected. Three of the four subjects, however, recorded eye irritation in both experiments (table).

\section{OCCUPATIONAL EXPOSURE}

The median eight hour TWA exposure concentration in the foundries studied was 3.5 (range 0.5 28) $\mathrm{mg} / \mathrm{m}^{3}$. The one hour sampling period concentrations ranged from $0 \cdot 1$ to $125 \mathrm{mg} / \mathrm{m}^{3}$ DMEA.

Two workers reported visual disturbances, starting seven to eight hours after the start of work, and lasting one hour after the end of work. Examination 40 minutes after the end of exposure showed a slight oedema of the corneal epithelium in one eye of one worker. The visual disturbances in the two workers were connected with a temporary (15 minute) malfunction of the exhaust ventilation during the last one hour sampling period of the workday. The eight hour 
Ocular effects of experimental exposure to different levels of dimethylethylamine (DMEA)

\begin{tabular}{|c|c|c|c|c|c|c|}
\hline $\begin{array}{l}\text { Exposure } \\
\left(\mathrm{mg} / \mathrm{m}^{3}\right)\end{array}$ & Subject & $\begin{array}{l}\text { Eye } \\
\text { irritation }\end{array}$ & $\begin{array}{l}\text { Visual } \\
\text { disturbances }\end{array}$ & $\begin{array}{l}\text { Latency } \\
\text { time } e^{\star}(h)\end{array}$ & $\begin{array}{l}\text { Corneal } \\
\text { oedema }\end{array}$ & $\begin{array}{l}\text { Duration } \dagger \\
\text { of "haze" (h) }\end{array}$ \\
\hline$\overline{0}$ & $\begin{array}{l}\mathbf{A} \\
\mathbf{B} \\
\mathbf{C} \\
\mathbf{D}\end{array}$ & $\begin{array}{l}\overline{-} \\
\overline{-} \\
-\end{array}$ & $\begin{array}{l}\overline{-} \\
\overline{-} \\
-\end{array}$ & $\begin{array}{l}\bar{z} \\
\overline{-} \\
-\end{array}$ & $\begin{array}{l}\overline{-} \\
\overline{-}\end{array}$ & $\begin{array}{l}\overline{-} \\
\overline{-} \\
-\end{array}$ \\
\hline $\begin{array}{l}10 \\
(8 \mathrm{~h})\end{array}$ & $\begin{array}{l}\text { A } \\
\text { B } \\
\text { C } \\
\text { D }\end{array}$ & $\begin{array}{l}- \\
\overline{-} \\
-\end{array}$ & $\begin{array}{l}- \\
- \\
- \\
-\end{array}$ & $\begin{array}{l}- \\
- \\
-\end{array}$ & $\begin{array}{l}- \\
- \\
- \\
-\end{array}$ & $\begin{array}{l}\bar{z} \\
\overline{-}\end{array}$ \\
\hline $\begin{array}{l}20 \\
(8 \mathrm{~h})\end{array}$ & $\begin{array}{l}\mathbf{A} \\
\mathbf{B}\end{array}$ & $\begin{array}{l}- \\
-\end{array}$ & $\overline{-}$ & $\begin{array}{l}- \\
-\end{array}$ & $\overline{-}$ & $\overline{-}$ \\
\hline $\begin{array}{l}40 \\
(8 \mathrm{~h})\end{array}$ & $\begin{array}{l}\text { A } \\
\text { B } \\
\text { C } \\
\text { D }\end{array}$ & $\begin{array}{l}+ \\
+ \\
+ \\
+\end{array}$ & $\begin{array}{l}\overline{+} \\
\overline{-}\end{array}$ & $\begin{array}{l}\frac{-}{6} \\
-\end{array}$ & $\begin{array}{l}- \\
+ \\
-\end{array}$ & $\begin{array}{l}- \\
- \\
-\end{array}$ \\
\hline $\begin{array}{l}50 \\
(8 \mathrm{~h})\end{array}$ & $\begin{array}{l}\text { A } \\
\text { B } \\
\text { C } \\
\text { D }\end{array}$ & $\begin{array}{l}+ \\
+ \\
+ \\
-\end{array}$ & $\begin{array}{l}+ \\
+ \\
+ \\
+\end{array}$ & $\begin{array}{l}7 \\
3 \\
6 \\
7\end{array}$ & $\begin{array}{l}- \\
+ \\
+ \\
+\end{array}$ & $\begin{array}{l}1 \\
3 \\
1 \\
1\end{array}$ \\
\hline $\begin{array}{l}100 \\
(15 \mathrm{~min})\end{array}$ & $\begin{array}{l}\text { A } \\
\text { B } \\
\text { C } \\
\text { D }\end{array}$ & $\begin{array}{l}+ \\
+ \\
+ \\
-\end{array}$ & $\begin{array}{l}- \\
- \\
-\end{array}$ & $\begin{array}{l}- \\
\overline{-} \\
-\end{array}$ & $\begin{array}{l}- \\
- \\
-\end{array}$ & $\begin{array}{l}\overline{-} \\
\overline{-}\end{array}$ \\
\hline $\begin{array}{l}150 \\
(15 \mathrm{~min})\end{array}$ & $\begin{array}{l}\mathbf{A} \\
\mathbf{B} \\
\mathbf{C} \\
\mathbf{D}\end{array}$ & $\begin{array}{l}+ \\
+ \\
+ \\
-\end{array}$ & $\begin{array}{l}- \\
- \\
-\end{array}$ & $\begin{array}{l}- \\
- \\
-\end{array}$ & $\begin{array}{l}- \\
- \\
-\end{array}$ & $\begin{array}{l}- \\
- \\
-\end{array}$ \\
\hline
\end{tabular}

ॠTime between onset of exposure and start of visual disturbances.

+ Duration of visual disturbances after end of the exposure.

$+=$ Effect.

$-=$ No effect.

TWA exposure concentrations of the two workers were 28 and $23 \mathrm{mg} / \mathrm{m}^{3}$, and the concentration for the last one hour sampling periods were 107 and $125 \mathrm{mg} /$ $\mathrm{m}^{3}$ DMEA. In a further study, on a day with proper exhaust ventilation (TWA exposure concentrations of DMEA of 14 and $5 \mathrm{mg} / \mathrm{m}^{3}$ ), no visual disturbances were registered.

\section{Discussion}

Experimental exposure of volunteers to $40-50 \mathrm{mg}$ / $\mathrm{m}^{3} \mathrm{DMEA}$ for eight hours and occupational full shift exposure concentrations of about $25 \mathrm{mg} / \mathrm{m}^{3}$ caused eye irritation, visual disturbances (haze, foggy vision), and oedema of the corneal epithelium. The effects in the industrial setting were probably associated with the short (one hour) peak exposures to $100-125 \mathrm{mg} / \mathrm{m}^{3} \mathrm{DMEA}$ that may well have been critical. During these one hour sessions, it can be assumed that short periods occurred when concentration of DMEA in air reached 300 to $500 \mathrm{mg} / \mathrm{m}^{3}$ (turnover rate of air about four times).

The discrepancy between our experimental data and the earlier reports of visual disturbances at industrial exposure concentrations of DMEA of six to $10 \mathrm{mg} / \mathrm{m}^{3}$ during eight hours, and about $30 \mathrm{mg} / \mathrm{m}^{3}$

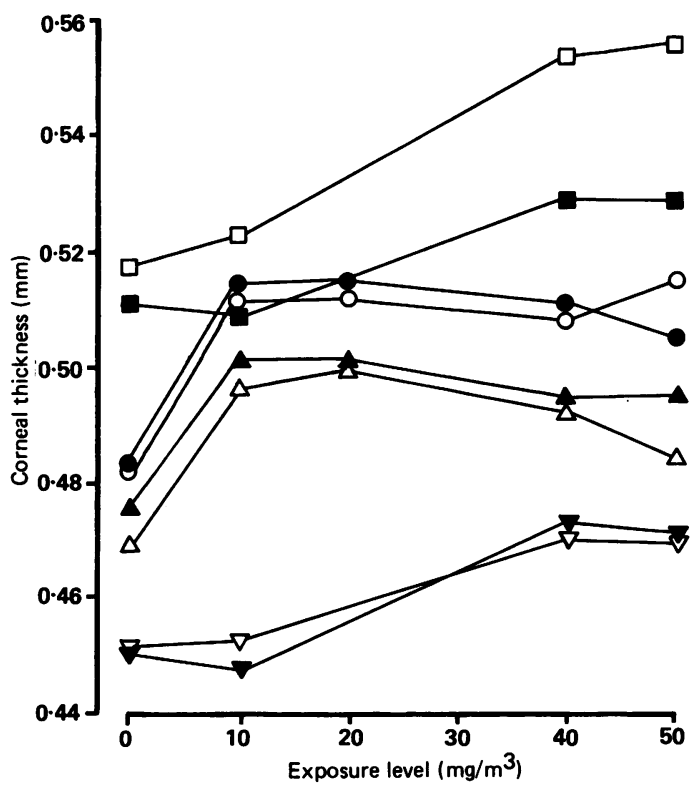

Corneal thickness (right eye, closed symbols; left eye, open symbols) after eight hours exposure to DMEA in four male volunteers (subject $A$, triangles base down; subject $B$, circles; subject $C$, squares; subject $D$, triangles base up). 
during 15 minutes ${ }^{10}$ are probably due to peak concentrations in the industrial setting. Such peaks may result from leaking core boxes - for example, failure to maintain pressure tight seals in the core box machine gaskets-or from malfunctioning ventilation systems.

The records for experiments with 15 minute exposure at concentrations of 80 and $160 \mathrm{mg} / \mathrm{m}^{3}$ DMEA, and eight hour exposure at concentrations of 40 and $50 \mathrm{mg} / \mathrm{m}^{3}$ indicate that irritation of the mucous membranes of the eyes seems to be the critical effect of short term exposure to DMEA rather than visual disturbances.

Although the visual disturbances themselves are not serious, they may result in a risk of accidents at work and in traffic, particularly at night, after the end of work. These risks and the irritating effects on the eyes may be avoided if TWA exposure concentrations of $20 \mathrm{mg} / \mathrm{m}^{3}$ are not exceeded and if (probably more important from a practical point of view) peak concentrations of DMEA are eliminated. Measurements of corneal thickness showed a slight but consistent increase during the experimental studies (without visual disturbances), which in some subjects may have started already at concentrations of $10 \mathrm{mg} / \mathrm{m}^{3}$. Lower concentrations were not tested.

The ocular effects were probably caused by a direct toxic effect of DMEA on the epithelial cells of the exposed parts of the cornea as no changes were found in unexposed parts of the cornea under the eyelids. The effects were reversible, and lasted not more than three hours after the end of exposure.

The concentrations of DMEA causing visual disturbances were two to three times higher than the corresponding concentrations of TEA. This may be due to less penetration of DMEA into the corneal layers, and a lower interference with the normal dehydration process, ${ }^{14}$ as DMEA is about five times less fat soluble than TEA. ${ }^{15}$

Ms Else-Britt Gustavsson and Ms Karin Paulsson supplied excellent technical help. The study was supported by a grant (88-0161) from the Swedish Environment Fund.
Requests for reprints to: Bengt Åkesson, Department of Occupational and Environmental Medicine, University Hospital, S-22185 Lund, Sweden.

1 Clayton GD, Clayton FE. Patty's Industrial Hygiene and Toxicology, 3rd ed. Vol IIb, Toxicology of aliphatic and alicyclic amines New York: Wiley Interscience, 1982:3135-73.

2 Albrecht WN, Stephenson RL. Health hazards of tertiary amine catalysts. Scand J Work Environ Health 1988;14:209-19.

3 Watrous RM, Martins JR, Schulz HN. Two chlorinated tertiary amines: Toxicity in industrial use. Industrial Medicine and Surgery 1948;17:237-41.

4 Watrous RM, Schulz HN. Cyclohexylamine, p-chloronitrobenzene, 2-aminopyridine: toxic effects in industrial use. Industrial Medicine and Surgery 1950;19:317-23.

5 Dernehl CU. Health hazards associated with polyurethane foams. J Occup Med 1966;7:59-62.

6 Brieger H, Hodes WA. Toxic effects of exposure to vapours of aliphatic amines. Archives of Industrial Hygiene and Occupational Medicine 1951;3:287-91.

7 Belin L, Wass U, Audunsson G, Mathiasson L. Amines: possible causative agents in the development of bronchial hyperreactivity in workers manufacturing polyurethanes from isocyanates. Br J Ind Med 1983;40:251-7.

8 Åkesson B, Bengtsson M, Florén I. Visual disturbances by industrial triethylamine exposure. Int Arch Occup Environ Health 1986;57:297-302.

9 Åkesson B, Florén I, Skerfving S. Visual disturbances after experimental human exposure to triethylamine. $\mathrm{Br} J$ Ind $\mathrm{Med}$ 1985;42:848-50.

10 Stephenson RL, Albrecht WN. Health hazard evaluation 85482-1730. Cincinnati: National Institute for Occupational Safety and Health, 1986.

11 Blome H, Hennig M. Messung ausgewählter aliphatischer und aromatischer Amine in der Luft von Arbeitbereichen. StaubReinhalt Luft 1984;44:27-32.

12 Schmittner $\mathrm{H}$. Arbeitsmedizinische und arbeitshygienische Untersuchungen beim Cold-Box- und Maskenformverfahren. Giesserei 1984;71:895-902.

13 Hansén L, Sollenberg J, Uggla C. Determination of dimethylethylamine in air samples from iron foundries by isotachophoresis. Scand J Work Environ Health 1985;11:307-10.

14 Potts AM, Rouse EF, Eiferman RA, Au PC. An unusual type of keratopathy observed in polyurethane workers and its reproduction in experimental animals. $\mathrm{Am} J$ Ind Med 1986;9:203-13.

15 Taft RW, Abraham MH, Famini GR, Doherty RM, Abboud JLM, Kamlet MJ. Solubility properties in polymers and biological media 5: An analysis of the physicochemical properties which influence octanol-water partition coefficients aliphatic and aromatic solutes. J Pharm Sci 1985;74:807-14.

16 Warren, Jr. DW, Selchan DF. An industrial hygiene appraisal of triethylamine and dimethylethylamine exposure limits in the foundry industry. Am Ind Hyg Assoc J 1988;49:630-4.

Accepted 23 July 1990 